\author{
Jacek Cybulski, Agata Witczak, Kamila Pokorska-Niewiada, Monika Zdyb
}

Katedra Toksykologii

Wydział Nauk o Żywności i Rybactwa

Zachodniopomorski Uniwersytet Technologiczny $w$ Szczecinie

Papieża Pawła VI 3, 71-459 Szczecin

E-mail: agata.witczak@zut.edu.pl

\title{
WYBRANE KSENOBIOTYKI ORGANICZNE W WODZIE PITNEJ A ZAGROŻENIA ZDROWIA
}

\section{WSTEP}

Woda warunkuje życie i funkcjonowanie organizmów żywych. Jest też ważnym elementem umożliwiajacym utrzymanie higieny ludzi, służy do przygotowywania żywności i napojów, a przede wszystkim bezpośrednio do konsumpcji. Stanowi również cenny surowiec dla przetwórstwa, jest również wykorzystywana do czyszczenia i sterylizacji pomieszczeń, aparatury przemysłu spożywczego, maszyn i urządzeń. Niezbędna jest także jako środek pomocniczy w procesach technologicznych, takich jak mycie, płukanie czy czyszczenie surowców (np. w przetwórstwie owocowo-warzywnym), a także jako dodatek $\mathrm{w}$ procesie produkcyjnym, np. w przetwórstwie mięsnym [np. kutrowanie (rozdrabnianie) mięsa $z$ wodą i lodem], jak również $\mathrm{w}$ browarnictwie czy wytwórniach alkoholi. Jest też niezbędnym surowcem do produkcji lodu czy pary, stosowanych w produkcji żywności (LUBKOWSKA 2016).

Woda wykorzystywana w przemyśle spożywczym, podobnie jak woda pitna, niezależnie od pochodzenia, musi spełniać określone parametry jakościowe, zgodnie z Rozporzadzeniem Ministra Zdrowia z 2017 r. (Dz. U. 2017, poz. 2294) (Tabela 1).

W krajach Unii Europejskiej nadrzędną i obowiazujaca dyrektywa, regulujaca parametry jakościowe wody przeznaczonej do spożycia dla ludzi, jest Dyrektywa Rady 98/83/ WE (DYREKTYWA 1998). Zgodnie $z$ jej zapisami woda pitna powinna być pozbawiona mikroorganizmów, pasożytów i szkodliwych substancji, które mogłyby być niebezpiecz- ne dla zdrowia ludzkiego. Co trzy lata kraje członkowskie sa zobligowane do składania do Komisji UE sprawozdania dotyczącego jakości lokalnej wody pitnej. Na tej podstawie raz na 5 lat dokonuje się weryfikacji parametrów mikrobiologicznych, chemicznych i wskaźnikowych oraz sposobów ich monitorowania. Dyrektywa nie odnosi się do naturalnych wód mineralnych i wód uznanych za lecznicze (DYREKTYWA 1998).

\section{RODZAJE ZANIECZYSZCZEŃ WODY PITNEJ}

W wodzie pitnej, ze względu na źródła jej pozyskiwania, mogą znaleźć się różne zanieczyszczenia, często trudne do usunięcia podczas rutynowych metod oczyszczania. Wiele $z$ tych związków nie jest również objętych koniecznością stałej kontroli (Dz. U. POZ. 2294 2017, DYREKTYWA 1998).

Źródła zanieczyszczeń wody można podzielić na: obszarowe, punktowe i liniowe. Źródła obszarowe dostarczają zanieczyszczeń $z$ dużych terenów, np. rolnych, leśnych, miejskich czy przemysłowych, a także składowisk odpadów. Źródłami punktowymi moga być np. wycieki ze zbiorników lub przewodów odprowadzajacych ścieki do rzek. Natomiast źródła liniowe dostarczaja zanieczyszczeń z dróg transportowych, linii kolejowych czy dróg wodnych (CHEŁMICKI 2001).

Do zanieczyszczeń wód zalicza się: detergenty, chloro- i bromopochodne węglowodorów aromatycznych, fenole, cyjanki, potencjalnie toksyczne pierwiastki śladowe (kadm, rtęć, ołów, chrom, nikiel, arsen) i wiele in- 
Tabela 1. Maksymalne dopuszczalne zawartości związków w wodzie przeznaczonej do picia, uwzględnione w Rozporządzeniu Ministra Zdrowia (Dz. U. POZ. 2294 2017).

\begin{tabular}{ll}
\hline Parametr & Maksymalne dopuszczalne stężenie \\
\hline Benzo(a)piren & $0,010 \mu \mathrm{g} / 1$ \\
$\Sigma$ Wielopierścieniowych węglowodorów aromatycznych & $0,10 \mu \mathrm{g} / 1$ (suma stężeń związków: \\
& - benzo(b)fluoranten, \\
& - benzo(k)fluoranten, \\
& - benzo(ghi)perylen, \\
& - indeno(1,2,3-cd)piren) \\
& $0,10 \mu \mathrm{g} / 1$ (Wartość tę stosuje się do poszczególnego pe- \\
Pestycydy (organiczne: insektycydy, herbicydy, fungi- & stycydu. W przypadku aldryny, dieldryny, heptachloru \\
cydy, nematocydy, akarycydy, algicydy, rodentycydy, & i epoksydu heptachloru wartość parametryczna wynosi \\
slimicydy, a także produkty pochodne) & $0,030 \mu g / 1)$ \\
& $0,50 \mu \mathrm{g} / 1$ \\
$\Sigma$ Pestycydów (suma poszczególnych pestycydów) & $0,015 \mathrm{mg} / 1$ \\
Bromodichlorometan & $0,030 \mathrm{mg} / 1$ \\
Trichlorometan (chloroform) & $100 \mu \mathrm{g} / 1$ Trihalometany - ogółem ( $\Sigma$ THM) - suma stężeń \\
Trihalometany - ogółem $(\Sigma$ THM) & związów: \\
& - trichlorometan (chloroform), \\
& - bromodichlorometan, \\
& - dibromochlorometan, \\
& - tribromometan (bromoform) \\
&
\end{tabular}

nych substancji. Obecność detergentów stosowanych powszechnie w procesach prania lub mycia, zarówno w gospodarstwach domowych, jak i zakładach przemysłowych, skutkuje pienieniem się wód i ograniczeniem dyfuzji tlenu $z$ powietrza. Źródłem cyjanków, fenoli, wielopierścieniowych węglowodorów aromatycznych i amin aromatycznych są często ścieki przemysłowe, pochodzace $z$ odpływów $z$ zakładów chemicznych, koksowni, gazowni, zakładów farmaceutycznych czy energetycznych (KRECHNIAK 2005, CHAU 2005, SIMAZAKI i współaut. 2015).

Ponadto, wtórnym źródłem zanieczyszczeń wody może być proces uzdatniania, tj. chlorowania wód, podczas którego dochodzi do powstania produktów ubocznych w postaci związków chlorowcowych, których prekursorem sa substancje humusowe zawarte naturalnie w wodzie. Do najgroźniejszych zalicza się trihalometany (THM) (DURMISHI i współaut. 2015).

\section{UZDATNIANIE WODY}

Zarówno wody powierzchniowe, jak i gruntowe moga zawierać zanieczyszczenia mineralne, organiczne, a także drobnoustroje. Aby mogły więc stanowić źródło wody pitnej, przed wprowadzeniem do sieci wodociagowej musza zostać poddane procesom uzdatniania (CYBULSKA 2012).

Proces uzdatniania wody obejmuje zazwyczaj następujace etapy: filtracje, napowietrzanie, koagulacje, sedymentację, sedymentację przez złoże piaskowe i węglowe oraz dezynfekcję. Filtracja polega na przejściu poddanej oczyszczaniu wody przez kratownice, mikrosita, filtry mechaniczne i siatkowe. Podczas tego etapu usuwane sa ciała stałe, zawiesiny organiczne i nieorganiczne, które moga spowodować uszkodzenie lub zamulenie urządzeń w dalszych etapach procesu. Następnym etapem jest napowietrzanie, który polega na natlenieniu wód powierzchniowych i usunięciu gazów, np. $\mathrm{CO}_{2}, \mathrm{CH}_{4}$ i $\mathrm{H}_{2} \mathrm{~S}$. Proces ten tworzy właściwe środowisko do hydrolizy i utleniania żelaza i manganu, a także zapobiega pogorszeniu cech organoleptycznych wody (KOWAL i ŚwIDERSKA-BRÓż 2007). Kolejnym etapem uzdatniania jest koagulacja $z$ siarczanem żelaza lub siarczanem glinu. Z koagulacja zwiazana jest często flokulacja, umożliwiajaca opadanie większych czasstek na dno. W wyniku wymieszania koagulantu $z$ woda, usuwane sa czastki koloidalne, decydujace o mętności i intensywno- 
ści barwy wody (skrobia, celuloza, białka i barwniki) (KRUPIŃSKA 2011).

Podczas następnej fazy uzdatniania woda poddawana jest sedymentacji zachodzacej w basenach, w których przepływa $z$ niewielka prędkościa. Pozbawiona zawiesin woda jest przenoszona do zbiornika, a pozostały na dnie osad jest usuwany. Następnie woda jest poddawana filtracji na złożu filtracyjnym piaskowym (drobnoziarnisty piasek podścielony żwirem). Do usunięcia zanieczyszczeń organicznych wykorzystuje się filtrację przez silnie porowate złoże węglowe (węgiel drzewny, antracyt, półkoks, węgiel kamienny lub brunatny) (JAHANSHAHI i TAGHIZADEH 2018).

Ostatnim etapem uzdatniania wody jest dezynfekcja, której zadaniem jest likwidacja organizmów chorobotwórczych. W przypad$\mathrm{ku}$, gdy $\mathrm{w}$ wodzie obecne sa glony, proces dezynfekcji wykonuje się również przed rozpoczęciem jej uzdatniania. Częstym sposobem dezynfekcji jest chlorowanie. Alternatywnie lub dodatkowo stosuje się także ozonowanie (BRANZ i współaut. 2017).

\section{PROBLEM JAKOŚCI WODY ZDATNEJ DO PICIA}

Mimo wieloetapowych procesów oczyszczania, jakość wody pitnej w różnych krajach może budzić obawy, ze względu na obecność w niej toksycznych zanieczyszczeń, zwłaszcza pozostałości pestycydów, farmaceutyków czy innych substancji genotoksycznych, często trudnych do usunięcia w klasycznym procesie uzdatniania (LI i wspó1aut. 2006, MEKOnEn i współaut. 2016). Dotyczy to między innymi niektórych związków zaliczanych do trwałych zanieczyszczeń organicznych (TZO), takich jak pestycydy chloroorganiczne, polichlorowane bifenyle (PCB), dioksyny czy heksachlorobenzen (HCB). Oprócz trwałości i odporności na czynniki chemiczne i biologiczne, zwiazki ten cechuje dobra rozpuszczalność w tłuszczach, a niska w wodzie, co sprzyja ich bioakumulacji w organizmach żywych (RODRIGUEz i współaut. 2008, WAN i współaut. 2010, PERELLó i współaut. 2012). Jednak pomimo ich niskiej rozpuszczalności w wodzie, obserwuje się w niej ich śladowe ilości, np. w formie zaadsorbowanej na czastkach stałych (LANA i współaut. 2008, PAWEŁCZYK 2013).

W ostatnich latach zwraca się uwagę, że woda pitna może być źródłem związków oddziałujacych na układ endokrynny. Do substancji tych, zwanych zwiazkami endokrynnie czynnymi (ang. endocrine disruptors, EDC), należą między innymi: bisfenol A (BPA), estrogeny, androgeny, dioksyny, polichlorowane bifenyle i pestycydy (np. DDT). BPA, będacy składnikiem (monomerem) two- rzyw poliwęglanowych, może przenikać do wód i żywności $z$ naczyń i opakowań. Niepokój wzbudzaja także doniesienia na temat obecności w wodzie śladowych ilości hormonów, czego przykładem może być obecność estradiolu, steroli, estriolu w ściekach, a także w oczyszczonych wodach powierzchniowych (FENG i współaut. 2016, WEE i ARIS 2017).

\section{WYBRANE ZANIECZYSZCZENIA OBECNE W WODZIE}

Obecność BPA i etynyloestradiolu wykryto, m.in. w wodzie w Brazylii (Melo i BRITO 2014), jednak na szczęście w niewielkich ilościach. Bisfenol A stwierdzono także w Libanie w wodzie butelkowanej (DHAINI i NASSIF 2014). EDC sa często wykrywane w źródłach wody pitnej w krajach na całym świecie, między innymi na Tajwanie (Gou i współaut. 2016), w Chinach (CAI i współaut. 2015, Li i współaut. 2015), Japonii (SIMAZAKI i współaut. 2015), Singapurze (XU i współaut. 2011, TRAN i współaut. 2013) czy w Hiszpanii (HuERTA-Fontela i współaut. 2011, DE JESUS GAFFNEY i współaut. 2015, WEE i ARIS 2017).

W latach 50-70. XX w. PCB były powszechnie produkowane na skalę przemysłowa. Dzięki swoim właściwościom, tj. niskiemu przewodnictwu elektrycznemu, wysokiemu przewodnictwu cieplnemu, odporności na wysokie temperatury oraz odporności na działanie kwasów i zasad, były szeroko stosowane w układach zamkniętych (akumulatory, transformatory, wymienniki ciepła) i otwartych (dodatki do farb, lakierów, smarów). Trwałość i toksyczność PCB oraz udowodniony szkodliwy wpływ na organizmy, spowodowały wprowadzenie zakazu ich produkcji i stosowania (PEREIRA 2004). Z uwagi na wieloletni okres połowicznego rozkładu, polichlorowane bifenyle do dzisiaj sa wykrywane $\mathrm{w}$ środowisku (WITCZAK i ABDEL-GAWAD 2012, FICEK i CZUPIOE 2013, PAWEECZYK 2013, WITCZAK i współaut. 2018). Przedostawaniu się PCB do wód i osadów dennych sprzyjały także wycieki i nieczystości pochodzące ze statków, czy też wycieki z kondensatorów i transformatorów (STEC i współaut. 2012). Ich obecność w glebie związana była $\mathrm{z}$ opadami aerozoli $\mathrm{z}$ powietrza oraz wymywaniem zakopanych w ziemi zanieczyszczeń przemysłowych (HE i współaut. 2011, WAN i współaut. 2011, KUMAR i współaut. 2012, FiCEK i CZuPiot 2013).

Zwiazki te przez wiele lat dostawały się do rzek, jezior i wód przybrzeżnych wraz ze ściekami przemysłowymi i komunalnymi oraz w wyniku transportu powietrznego. Przykładowo, w Egipcie, gdzie głównym źró- 
dłem wody pitnej jest rzeka Nil, obserwuje się nadal wysoki stopień zanieczyszczenia wód polichlorowanymi bifenylami (MEGAHED i współaut. 2015).

Przykładem badań prowadzonych w Polsce moga być wyniki uzyskane przez SULEJ i współaut. (2011), którzy stwierdzili obecność polichlorowanych bifenyli w ilościach 60-440 ng/1 w wodach spływowych $z$ terenu lotniska w Gdańsku. Jak podaje PAWEŁCZYK (2013), średnie stężenie sumy PCB w wodzie, pochodzacej $z$ ujęć we Wrocławiu, kształtowało się na poziomie $452 \mathrm{ng} / 1$. Niższe zawartości, od 5,2 do $190,8 \mathrm{ng} / 1$, stwierdzono w Czechach w południowych Morawach (LANA i współaut. 2008). W południowej Turcji zaś wartości te były znacznie wyższe niż obserwowane w innych krajach Europy i wynosiły 505-2377 ng/1 (AYDIN i współaut. 2004). Badania prowadzone w Chinach wykazały duże rozpiętości stężeń sumy PCB w wodzie rzeki Pearl River, Minjiang (91-2473 $\mathrm{ng} / 1)$, zaś dużo niższe poziomy zanotowano w rzece Jangcy $(0,21-44,4 \mathrm{ng} / 1) \quad(\mathrm{HE}$ i współaut. 2011), a także w Kunming na południu Chin (13-72 ng/1) (WAN i współaut. 2011). Biorac pod uwage obszar Afryki, w Nigerii i Etiopii również stwierdzono wysokie stężenia sumy PCB w wodach rzecznych (30-2930 ng/1) (EZEMONYE 2005, OKENIYIA i współaut. 2009). Natomiast w rzece Jamun w Indiach zanotowano znacznie niższe stęże-

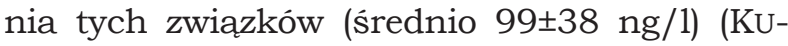
MAR i współaut. 2012).

Dioksyny obejmują grupe 75 kongenerów PCDD (polichlorowane dibenzo- $p$-dioksyny) i 135 PCDF (polichlorowane dibenzofurany). Ich obecność w przyrodzie jest głównie wynikiem ubocznym działalności człowieka, tj. wytwarzania energii, spalania odpadów, wycieków, produkcji chlorowanych związków (np. impregnaty), a także wytopu metali, m.in. aluminium (PEREIRA 2004).

Wyniki badań RODRIGUEz i współaut. (2008) wykonanych w Perth (Australia) udowodniły występowanie niskich, nie zagrażających zdrowiu ludzi, stężeń dioksyn w ściekach i wodach powierzchniowych. Potwierdza to fakt, że woda ma znikomy udział (ok. $0,01 \%$ ) w ogólnym narażeniu ludzi na dioksyny, w porównaniu $z$ żywnością, szczególnie pochodzenia zwierzęcego.

Inną ważna grupę zanieczyszczeń stanowia wielopierścieniowe węglowodory aromatyczne (WWA), których źródłem moga być pożary lasów czy procesy naturalnie zachodzace w środowisku, np. biosynteza i przemiany zwiazków pod wpływem mikroorganizmów w glebie. Jednak główną przyczyna ich występowania w wodach różnego pochodzenia jest działalność człowieka. Do głównych źródeł należą: przetwarzanie wę- gla kamiennego i ropy naftowej w hutach i koksowniach, spalanie paliw i drewna, utylizacja odpadów, asfalt, $z$ których zwiazki te dostaja się do gleby, a następnie do wód. Znaczacy wpływ mają także ścieki przemysłowe i gospodarcze oraz wysypiska odpadów. WWA w wodzie pitnej wykryto w wielu krajach świata, między innymi w Iranie, Egipcie (2,01-733,01 ng/1) czy w Chinach, gdzie zawartości te były nieznacznie mniejsze (KARYAB i współaut. 2013).

Trihalometany (THM) sa zwiazkami, zaliczanymi do halogenowych pochodnych węglowodorów, do których należą: chloroform, bromoform, dibromometan i dichlorometan (DURMishi i współaut. 2015). Moga one powstawać samoczynnie podczas uzdatniania wód w procesie dezynfekcji jako produkt uboczny, w wyniku reakcji środka dezynfekujacego (chlor, ozon, chloraminy, brom, jod) $z$ naturalnie występujaca materia organiczna (np. substancje humusowe). Ich tworzeniu sprzyja także kontakt ze ściekami przemysłowymi, zawierajacymi chlor. Występują również naturalnie w wodach powierzchniowych, wraz $z$ substancami humusowymi (prekursorami). Organizm człowieka może mieć kontakt ze związkami THM podczas spożycia skażonej wody oraz przez skórę (RICHARDSON i współaut. 2007, PANTELAKI i VOUTSA 2017). Badania wody pitnej przeprowadzone w Stanach Zjednoczonych w Kalifornii w latach 2014-2015 wykazały sumaryczne stężenie THM średnio na poziomie $27 \mu \mathrm{g} / 1$, przy czym maksymalne stężenie tych związków wyniosło $229 \mu \mathrm{g} / 1$ (ОЕHнA 2018).

Pestycydy, do których zaliczane sa zwiazki o bardzo różnorodnej strukturze chemicznej i właściwościach, od lat wykorzystywane sa do zwalczania chwastów, stymulowania wzrostu upraw czy unieszkodliwiania szkodników (insektycydy). Ze względu na właściwości biobójcze, obecność ich pozostałości w wodzie pitnej może wpływać na obniżenie jej jakości i stwarzać zagrożenie dla konsumentów (Younes i Galal- GORCHEV 2000, BRZEZIŃSKI i SZUTOWSKI 2005, ORMAD i współaut. 2008). Przyczyna dostawania się insektycydów do wód może być nierozważne i nieświadome obchodzenie się $z$ pestycydami, niewłaściwe ich przechowywanie, niedbała utylizacja pojemników czy używanie przestarzałych środków, co stało się m.in. głównym powodem zanieczyszczenia wód w Etiopii i Pakistanie (ESSUMANG i współaut. 2009, HASHIM 2015, MEKONEN i współaut. 2016).

Spośród wielu klas insektycydów za najgroźniejsze uznane zostały insektycydy chloroorganiczne (OCP), do których zalicza się: aldrynę, dieldrynę, chlordan, DDT, DDA, DDD, endrynę, heptachlor, mirex, toksafen $\mathrm{i}$ 
Tabela. 2. Zawartość pestycydów w wodzie pitnej w Szczecinie w latach 2014-2017 (RAPORT RSSE Szczecin 2017).

\begin{tabular}{|c|c|c|c|c|c|c|c|c|c|c|c|c|}
\hline \multicolumn{13}{|c|}{ Stężenie pestycydów w wybranych miesiącach w latach 2014-2017 [ug/1] } \\
\hline \multirow{2}{*}{$\begin{array}{l}\text { Nazwa } \\
\text { Pestycydu }\end{array}$} & \multicolumn{4}{|l|}{2014} & \multicolumn{4}{|l|}{2015} & \multicolumn{4}{|c|}{2016 i 2017} \\
\hline & II2 & III & $\mathrm{V}$ & $\mathrm{X}$ & II & III & $\mathrm{V}$ & $\mathrm{X}$ & II & III & $\mathrm{V}$ & $\mathrm{X}$ \\
\hline Chlordan & 0,1 & 0,004 & 0,004 & 0,004 & 0,008 & 0,008 & 0,008 & $<$ LOQ1 & $<$ LOQ & $<$ LOQ & $<\mathrm{LOQ}$ & $<\mathrm{LOQ}$ \\
\hline 8-HCH & 0,1 & 0,004 & 0,004 & 0,004 & 0,004 & 0,004 & 0,004 & $<$ LOQ & $<$ LOQ & $<$ LOQ & $<\mathrm{LOQ}$ & $<$ LOQ \\
\hline Lindan & 0,1 & 0,004 & 0,004 & 0,004 & 0,004 & 0,004 & 0,004 & $<$ LOQ & $<$ LOQ & $<$ LOQ & $<\mathrm{LOQ}$ & $<$ LOQ \\
\hline pp' DDT & 0,1 & 0,004 & 0,004 & 0,004 & 0,004 & 0,004 & 0,004 & $<\mathrm{LOQ}$ & $<\mathrm{LOQ}$ & $<\mathrm{LOQ}$ & $<\mathrm{LOQ}$ & $<$ LOQ \\
\hline op' DDT & 0,1 & 0,004 & 0,004 & 0,004 & 0,004 & 0,004 & 0,004 & $<$ LOQ & $<$ LOQ & $<$ LOQ & $<\mathrm{LOQ}$ & $<$ LOQ \\
\hline $\mathrm{a}-\mathrm{HCH}$ & 0,1 & 0,004 & 0,004 & 0,004 & 0,004 & 0,004 & 0,004 & $<$ LOQ & $<$ LOQ & $<$ LOQ & $<\mathrm{LOQ}$ & $<$ LOQ \\
\hline$\beta-\mathrm{HCH}$ & 0,1 & 0,004 & 0,004 & 0,004 & 0,004 & 0,004 & 0,004 & $<$ LOQ & $<$ LOQ & $<$ LOQ & $<\mathrm{LOQ}$ & $<$ LOQ \\
\hline Epoksyd & 0,03 & 0,004 & 0,004 & 0,004 & 0,008 & 0,008 & 0,008 & $<\mathrm{LOQ}$ & $<$ LOQ & $<$ LOQ & $<\mathrm{LOQ}$ & $<$ LOQ \\
\hline $\begin{array}{l}\text { heptachloru } \\
\text { Aldryna }\end{array}$ & 0,03 & 0,004 & 0,004 & 0,004 & 0,004 & 0,004 & 0,004 & $<\mathrm{LOQ}$ & $<\mathrm{LOQ}$ & $<\mathrm{LOQ}$ & $<\mathrm{LOQ}$ & $<\mathrm{LOQ}$ \\
\hline Endryna & 0,1 & 0,004 & 0,004 & 0,004 & 0,004 & 0,004 & 0,004 & $<$ LOQ & $<$ LOQ & $<$ LOQ & $<$ LOQ & $<$ LOQ \\
\hline Dieldryna & 0,03 & 0,004 & 0,004 & 0,004 & 0,004 & 0,004 & 0,004 & $<\mathrm{LOQ}$ & $<$ LOQ & $<$ LOQ & $<\mathrm{LOQ}$ & $<$ LOQ \\
\hline $\mathrm{HCB}$ & 0,1 & 0,004 & 0,004 & 0,004 & 0,004 & 0,004 & 0,004 & $<\mathrm{LOQ}$ & $<$ LOQ & $<\mathrm{LOQ}$ & $<\mathrm{LOQ}$ & $<$ LOQ \\
\hline Heptachlor & 0,03 & 0,004 & 0,004 & 0,004 & 0,004 & 0,004 & 0,004 & $<$ LOQ & $<$ LOQ & $<$ LOQ & $<\mathrm{LOQ}$ & $<$ LOQ \\
\hline
\end{tabular}

${ }^{1}<$ LOQ (poniżej granicy oznaczalności); LOQ wynosi 0,004 dla $\delta$-HCH, $\gamma$-HCH, pp'DDT, a-HCH, $\beta$-HCH, aldryny, dieldryny, endryny, HCB, heptachloru i op'DDT. LOQ wynosi 0,008 dla chlordanu i epoksydu heptachloru; II miesiac wykonania badania

heksachlorocykloheksan $(\mathrm{HCH})$. Ich czas rozkładu (w 95\%) sięga 1-30 lat (GROTOWSKA i współaut. 2018). W Chinach w wodzie pitnej zanotowano obecność sumy $\mathrm{HCH}(5,54-$ $13,08 \mathrm{ng} / 1)$ i sumy DDT $(0,17-4,47 \mathrm{ng} / 1)$, jednak zawartości te uznano za bezpieczne (WEI i współaut. 2015, LEHMANN i współaut. 2017).

Pomimo wprowadzenia ograniczeń dotyczacych stosowania chloroorganicznych pestycydów (OCP), w Chinach nadal wykorzystuje się DDT do produkcji dikofolu, co skutkuje stałym transferem tych zwiazków do środowiska. SHAO i współaut. (2016) udowodnili wyraźny spadek sumy DDT w wodach powierzchniowych w Pekinie, od 91,81 $\mathrm{ng} / 1$ (2002) do 0,257 ng/1 (2015-2016). Dane literaturowe wskazuja, że izomery $\mathrm{HCH}$ i DDT nadal znajdowane sa w wodach stanowiacych źródła wody pitnej na całym świecie. Najwyższe stężenia sumy DDT i $\mathrm{HCH}$ zaobserwowano w Afryce $(\Sigma \mathrm{HCH}$ 6-234 ng/1 i $\Sigma D D T$ 8-239 ng/1) i Azji ( $\Sigma \mathrm{HCH} 76-$ 100 ng/1 i EDDT 116-848 ng/l) (EL BOURAIE i współaut. 2011, KAUSHIK i współaut. 2012).

Według badań PAWEŁCZYKA (2013), w wodzie pochodzącej $z$ ujęć we Wrocławiu stwierdzono zawartość pozostałości pestycy- dów chloroorganicznych na poziomie 73,53 $\mathrm{ng} / 1$.

Badania wody wodociagowej prowadzone przez Powiatową Stację Sanitarno-Epidemiologiczną w Szczecinie na przestrzeni lat 2014-2017 wykazały zmniejszający się poziom pestycydów chloroorganicznych, od zawartości_sięgającej NDS (wartość najwyższego dopuszczalnego stężenia) do pozostałości na granicy LOQ (granica oznaczalności) (RAPORT RSSE SzCZECIN 2017) (Tabela 2).

Świadczy to o zdecydowanej poprawie jakości wody pochodzacej ze szczecińskich wodociagów, co wynika prawdopodobnie $z$ wdrożenia nowych technologii oczyszczania i uzdatniania wody oraz dbałości o stan techniczny sieci wodociagowej.

\section{WPEYW OBECNOŚCI NIEKTÓRYCH KSENOBIOTYKÓW W WODZIE PITNEJ NA ZDROWIE CZŁOWIEKA}

Siła działania toksycznego dioksyn i zwiąków dioksynopodobnych jest ściśle zwiazana $z$ ich budowa chemiczna i właściwościami fizykochemicznymi. Właściwości PCDD i PCDF, takie jak trwałość i lipofilowość powodują ich silną sorpcję na glebie i 
pyłach zwieszonych oraz słaba biodegradację. W konsekwencji kumuluja się w osadach dennych i ściekowych oraz biokumuluja się $\mathrm{w}$ organizmach wodnych i ziemnych (przede wszystkim w tkance tłuszczowej) głównie izomery tetra-, penta-, heksa- hepta i okta.

Dioksyny wykazują zróżnicowaną siłe działania toksycznego. Jest to uzależnione od liczby atomów chloru w cząsteczce poszczególnych kongenerów oraz wrażliwości gatunkowej organizmu, który podlega ich działaniu. Działanie toksyczne dioksyn może objawiać się po latach kumulacji w organizmie $\mathrm{w}$ postaci złożonego uszkodzenia narządów wewnętrznych, upośledzenia układu hormonalnego, immunologicznego, rozrodczego, a także działania genotoksycznego, wpływajac na strukture DNA (FIEDLER 2003).

Jak podaja GROCHOWALSKI i CHRZASZCZZ (2000), średni czas połowicznego trwania $\mathrm{w}$ organizmie ludzkim PCDD i PCDF szacuje się na 7-10 lat, co powoduje, że wielokrotne narażenie nawet na małe stężenia dioksyn może negatywnie wpływać na zdrowie człowieka, a przenikanie do płodu oraz mleka matki powoduje przekazanie tych zwiazków potomstwu i wydłużenie okresu narażenia.

$\mathrm{PCB}$, w stosunku do PCDD/F, wykazuja wyższe stopnie biokumulacji $\mathrm{w}$ łańcuchu troficznym, a głównie w środowisku wodnym (RODRIGUEZ i współaut. 2008).

Polichlorowane bifenyle sa zwiąkami toksycznymi i immunosupresyjnymi. Sa one transportowane przez lipidy krwi do watroby i tkanki tłuszczowej, gdzie ulegaja kumulacji. Oprócz działania szkodliwego na wątrobę, moga wpływać negatywnie na układ nerwowy i hormonalny, zwiększając metabolizm hormonów tarczycy, czy powodować zaburzenia rozrodczości, a także występowanie wad rozwojowych u dzieci matek narażonych na PCB (STEC i współaut. 2012).

WWA dostaja się do organizmu głównie podczas spożywania pokarmów smażonych, wędzonych i grillowanych, a efekty ich toksycznego działania zwiazane sa $z$ uszkodzeniem DNA, martwica hepatocytów, uszkodzeniem kłębuszków nerkowych i występowaniem nowotworów (LORENZI i współaut. 2011).

$Z$ uwagi na kancerogenność, genotoksyczność i mutagenność THM, ich zawartość jest ściśle kontrolowana. Zgodnie $z$ obowiazującym Rozporządzeniu Ministra Zdrowia $z$ dnia 7 grudnia 2017 r. w sprawie jakości wody przeznaczonej do spożycia przez ludzi, łączna suma THM w wodzie nie może przekraczać $100 \mu \mathrm{g} / 1$. Przekroczenie tej wartości może przyczyniać się do wzrostu zachorowalności na nowotwory, $\mathrm{m}$. in. pęcherza moczowego, watroby, a także zwiększania ryzy- ka poronień (RICHARDSON i współaut. 2007, WANG i współaut. 2007, KENNETH 2010, OEHHA 2018).

Toksyczność pestycydów różni się w zależności od budowy tych substancji. Może powodować zatrucie ostre lub przewlekłe. Zatrucia ostre zwiazane sa $z$ praca zawodową czy praca $\mathrm{w}$ gospodarstwie, opieraja się na biochemicznym oddziaływaniu na obwodowy i centralny układ nerwowy, powodujac bóle i zawroty głowy, zmęczenie, wysypki, zaburzenie koncentracji, osłabienie, drżenie, ataki paniki. Zatrucia przewlekłe stanowia wynik gromadzenia się substancji szkodliwych w organizmie, często nie wykazując poczatkowo widocznych objawów. Związki te, w zależności od klasy toksyczności i właściwości, moga przenikać przez błony białkowo-lipidowe, kumulować się w organizmie i oddziaływać na układ nerwowy, serce, mózg oraz narządy odpowiadające za detoksykację: watrobę i nerki (GAEUSZKA i współaut. 2011, WEI i współaut. 2015).

Ze względu na toksyczne działanie pestycydów, podlegają one kontroli w wodzie pitnej, a ich suma nie powinna przekraczać $0,50 \mu \mathrm{g} / 1$ (Tabela 1) (YounEs i Galal-GoRCHEV 2000, KRECHNIAK 2005).

\section{PODSUMOWANIE}

W wodzie pitnej, w zależności od źródła jej pozyskiwania, moga znaleźć się różnorodne zanieczyszczenia, w tym często trudne do usunięcia podczas rutynowych metod oczyszczania.

Z przeprowadzonej analizy wynika, że obecność trwałych zanieczyszczeń organicznych $\mathrm{w}$ wodach powierzchniowych, jak również $\mathrm{w}$ wodzie pitnej, jest nadal aktualna i występuje $\mathrm{w}$ wielu regionach świata. Istniejace dyrektywy unijne i rozporzadzenia krajowe, limitujące najwyższe dopuszczalne zawartości różnych zanieczyszczeń w wodzie przeznaczonej do picia, wydają się często niewystarczajace. Brak jest w nich parametrów jakościowych dla niektórych substancji, istotnych $z$ punktu widzenia toksykologicznego, między innymi polichlorowanych bifenyli, nadal obecnych $\mathrm{w}$ środowisku czy też pojawiających się coraz częściej pozostałości środków farmaceutycznych lub zwiąków ograniczających palność np. tworzyw sztucznych. Dlatego rozszerzenie listy niezbędnych badań dotyczacych wody pitnej wpłynęłoby na wzrost bezpieczeństwa zdrowotnego konsumentów.

\section{Streszczenie}

Woda wykorzystywana w przemyśle spożywczym oraz do przygotowywania żywności czy napojów, musi spełniać wymogi wody do picia. Celem pracy było przeprowadzenie analizy piśmiennictwa dotyczącego najczę- 
ściej występujących ksenobiotyków organicznych w wodzie pitnej, a także w innych rodzajach wód, mogących być źródłem wody pitnej. Problem obecności trwałych zanieczyszczeń organicznych $\mathrm{w}$ wodach powierzchniowych, jak również w wodzie pitnej jest nadal aktualny i występuje w wielu regionach świata. W wodzie pitnej, w zależności od źródła jej pozyskiwania, moga znaleźć się różnorodne zanieczyszczenia, w tym często trudne do usunięcia podczas rutynowych metod oczyszczania. Należą do nich na przykład dioksyny (PCDD), polichlorowane bifenyle (PCB), heksachlorobenzen (HCB), chloroorganiczne pestycydy, wielopierścieniowe węglowodory aromatyczne (WWA), trihalometany (THM), pozostałości farmaceutyków. Istniejące dyrektywy unijne oraz rozporządzenia krajowe, określające dopuszczalne stężenia zanieczyszczeń w wodzie przeznaczonej do picia, nie obejmuja wielu z tych związków. Dlatego też rozszerzenie listy niezbędnych badań dotyczących wody pitnej wpłynęłoby na wzrost bezpieczeństwa zdrowotnego konsumenta.

\section{LITERATURA}

Aydin M. E., SARI S., ÖZCAN S., WichmanN H., BAHADIR M., 2004. Polychlorinated biphenyls in waste water of Konya-Turkey. Fresenius Environ. Bull. 13, 1090-1093.

Branz A., Levine M., Lehmann L., Bastable A., Ali S. I., KadIR K., YATES T., BlOOM D., LANTAGNE D., 2017. Chlorination of drinking water in emergencies: Systematic review of knowledge recommendations for implementation and research needed. Waterlines 36, 4-39.

BRZEZIŃSKI I., SZUTOWSKI M. M., 2005. Toksykologia pestycydów. [W:] Toksykologia wspótczesna. SENCZUK W. (red.). Wyd. Lekarskie PZWL. Warszawa, 544-546.

CAI M. Q., WANG R., FENG L., ZHANG L. Q., 2015. Determination of selected pharmaceuticals in tap water and drinking water treatment plant by highperformance liquid chromatography-triple quadrupole mass spectrometer in Beijing, China. Environ. Sci. Pollut. Res. 22, 18541867.

CHAU K. W., 2005. Characterization of transboundary POP contamination in aquatic ecosystems of Pearl River Delta. Marine Pollut. Bull. 51, 960-965.

CHEEMICKI W., 2001. Woda. Zasoby, degradacja, ochrona. Wydawnictwo Naukowe PWN, Warszawa.

CYBULSKA E., 2012. Woda jako składnik żywności. [W]: Chemia żywności. SIKORSKI Z. (red.). Wydawnictwo WNT, Warszawa, 79-81.

de Jesus Gaffney V., Almeida C. M., RodriguES A., FERREIRA E., BENOliel M. J., CARDOSO V.V., 2015. Occurrence of pharmaceuticals in a water supply system and related human health risk assessment. Water Res. 72, 199208.

DHAINI H. R., NASSIF R. M., 2014. Exposure assessment of endocrine disruptors in bottled drinking water of Lebanon. Environ. Monitor. Assess. 186, 5655-5662.

DuRMishi B. H., REKA A. A., GJULAdin-HELlON T., ISMAILI M., SRBINOVSKI M., 2015. Disinfection of drinking water and trihalomethanes: a review. Int. J. Adv. Res. Chem. Sci. 2, 45-56.

DZ. U. POZ. 2294 (DZIENNIK UsTAW), 2017. Rozporzadzenie Ministra Zdrowia $z$ dnia 7 grudnia 2017 r. $w$ sprawie jakości wody przeznaczonej do spożycia przez ludzi. http://prawo. sejm.gov.pl/isap.nsf/DocDetails.xsp?id=WDU20170002294
DYREKTYWA, 1998. Dyrektywa Rady 98/83/WE z dnia 3 listopada 1998 r. w sprawie jakości wody przeznaczonej do spożycia przez ludzi. https: / / eur-lex.europa.eu/legal-content/PL/ TXT/?uri=CELEX\%3A31998L0083

El Bouraie M., El Barbary A., YeHIA M., 2011. Monitoring of chlorinated hydrocarboncompounds residues in surface water and bed sediment samples from El Rahawy drain, Egypt. Int. J. Environ. Sci. 1, 1931-1947.

EssumANG D. K., TOGOH G. K., CHOKKY L., 2009. Pesticide residues in the water and fish (lagoon tilapia) samples from lagoons in Ghana. Bull. Chem. Soc. Ethiopia 23, 19-27.

EZEMONYE L., 2005. Polychlorinated biphenyls $(P C B)$ levels and distribution in Ethiope and Benin Rivers of the Niger Delta Nigeria: surface water and sediments. Int. J. Environ. Stud. 62, 491-504.

Feng L., Yang G., ZHU L., Xu J., Xu X., Chen Y., 2016. Distribution and risk assessment of endocrine-disrupting pesticides in drinking water sources from agricultural watershed. Water Air Soil Pollut. 227, 23.

FiCEK A., CZUPIOE J., 2013. PCB - szkodliwe $k$ senobiotyki $w$ środowisku. LAB Laboratoria Aparatura Badania 18, 28-31.

FIEDLER H., 2003. Dioxins and furans (PCDD/ PCDF). [W:] Persistent Organic Pollutants. The Handbook of Environmental Chemistry. Vol. 3. FIEDLER H. (red.). Springer, Berlin, Heidelberg, 123-201.

GaŁuszka A., Migaszewski Z. M., Manecki P., 2011. Pesticide burial grounds in Poland: A review. Environ. Int. 37, 1265-1272.

Gou Y. Y., LiN S., QUE D. E., TAYO L. L., LIN D. Y., Chen K. C., Chen F. A., Chiang P. C., Wang G. S., Hsu Y. C., Chuang K. P., 2016. Estrogenic effects in the influents and effluents of the drinking water treatment plants. Environ. Sci. Pollut. Res. 23, 8518-8528.

GROCHOWALSKI A., CHRZASZCZ R., 2000. The result of the large scale determination of PCDDs, PCDF's and coplanar PCBs in Polish food product samples using GCMS/MS technique. Organohalogen Compounds 47, 306-310.

GROTOWSKA M., JANDA K., JAKUBCZYK K., 2018. Wpływ pestycydów na zdrowie człowieka. Pomeranian J. Life Sci. 64, 42-50.

HASHIM M., 2015. Pesticides and drinking water. J. Advanc. Bot. Zool. 3, 1-5.

He H., Hu G. J., Sun C., Chen S., YANG M., LI J., 2011. Trace analysis of persistent toxic substances in the main stream of Jiangsu section of the Yangtze River China. Environ. Sci. Pollut. Res. 18, 638-648.

Huerta-Fontela M., Galceran M. T., Ventura F., 2011. Occurrence and removal of pharmaceuticals and hormones through drinking water treatment. Water Res. 45, 1432-1442.

Jahanshahi M., TAGHIZADEH M. M., 2018. Pre-sedimentation tank effects on water treatment unit operation. Environ. Qual. 28, 35-42.

KARYAB H., YUNESIAN M., NASSERI S., MAHVI A. H., AHMadKhaniHa R., RAStKaRi N., NABIZADEH R., 2013. Polycyclic aromatic hydrocarbons in drinking water of Tehran. J. Environ. Health Sci. Engin. 11, 1-7.

KAUSHIK C. P., SHARMA H. R., KAUSHIK A., 2012. Organochlorine pesticide residues in drinking water in the rural areas of Haryana India. Environ. Monitor. Assess. 184, 103-112.

KENNETH P., 2010. Carcinogens in drinking water: The epidemiologic evidence. Rev. Environ. Health 25, 9-16. 
KOWAL A., ŚWIDERSKA-BRÓż M., 2007. Oczyszczanie wody. Podstawy teoretyczne i technologiczne, procesy $i$ urzadzenia. Wydawnictwo $\mathrm{Na}-$ ukowe PWN, Warszawa.

KRECHNIAK J., 2005. Toksykologia środowiskowa. [W:] Toksykologia współczesna. SEŃCZUK W. (red.). Wyd. Lekarskie PZWL. Warszawa, 680683.

KRUPIŃSKA I., 2011. Wpływ czasu flokulacji na jakość wody uzdatnionej. Inżynieria i Ochrona Środowiska 14, 17-28.

Kumar B., Singh S., Mishra M., Kumar S., SharMA C., 2012. Assessment of polychlorinated biphenyls and organochlorine pesticides in water samples from the Yamuna River. J. Xenobiot. 2, 28-34

LANA R., VAVROVA M., CASlavsky J., Skoumalova M., BILKOVA A., SUCMAN E., 2008. PCBs in samples from the environment of the southern Moravia region Czech Republic. Bull. Environ. Contamin. Toxicol. 81, 574-577.

Li Y. Q., WU Y. L., ChEN Y. G., Kong Z. M., 2006. Genotoxicity evaluation and a primary risk assessment of organic pollutants in the drinking water sources of Nanjing, China. J. Environ. Sci. 18, 983-988.

Li Z., Xiang X., Li M., Ma Y., WANG J., LiU X., 2015. Occurrence and risk assessment of pharmaceuticals and personal care products and endocrine disrupting chemicals in reclaimed water and receiving groundwater in China. Ecotoxicol. Environ. Safety 119, 74-80.

LORENZI D., ENTWistle J. A., CAVE M., DEAN J. R., 2011. Determination of polycyclic aromatic hydrocarbons in urban street dust: implications for human health. Chemosphere 83, 970-977.

ŁUBKOWSKA B., 2016. Rola wody $w$ życiu człowie$k a$ írodowisku. Wydawnictwo Wyższej Szkoły Zarządzania. Gdańsk, 20-37.

Megahed A. M., Dahshan H., ABD-El-Kader M., MOHAMED ABD-Ellal A. M., Elbana M. H., NABAwY E., Mahmoud H. A., 2015. Polychlorinated biphenyls water pollution along the River Nile, Egypt. Sci. World J. 2015, 7.

MEKonen S., ARGAW R., Simanesew A., HoubraKEN M., SENAEVE D., AmbelU A., SPANOGHE P., 2016. Pesticide residues in drinking water and associated risk to consumers in Ethiopia. Chemosphere 162, 252-260.

Melo S. M., BRito N. M., 2014. Analysis and occurrence of endocrine disruptors in Brazilian water by HPLC-Fluorescence detection. Water Air Soil Pollut. 225, 1783-1789.

OEHHA, 2018. Trihalomethanes in drinking water: chloroform, bromoform, bromodichloromethane, dibromochloromethane. Public Health Goal, California. https://oehha.ca.gov/media/downloads/crnr/thmsdraft100518.pdf

OKENIYIA S. O., EGWAIKHIDEB P. A., AKPORHONORC E. E., OBAZED I. E., 2009. Distribution of or ganochlorine and polychlorinated pesticide residue in water bodies of some rivers in Northern Nigeria. Electron. J. Environ. Agricult. Food Chem. 8, 1269-1274.

Ormad M. P., Miguel N., Claver A., Matesanz J. M., OVELlEIRO J. L., 2008. Pesticides removal in the process of drinking water production. Chemosphere 71, 97-106.

PANTELAKI I., VOUTSA D., 2017. Formation of iodinated THMs during chlorination of water and wastewater in the presence of different iodine sources. Sci. Total Environ. 613-614, 389397.

PAWEECZYK A., 2013. Assessment of health risk associated with persistent organic pollutants in water. Environ. Monitor. Assess. 185, $497-$ 508.

PEREIRA M., 2004. Polychlorinated dibenzo-p-dioxins (PCDD), dibenzofurans $(P C D F)$ and polychlorinated biphenyls (PCB): main sources, environmental behaviour and risk to man and biota. Química Nova 27, 934-943.

Perelló G., Gómez-Catalán J., Castell V., LloBET J. M., DOMINGO J. L., 2012. Assessment of the temporal trend of the dietary exposure to $P C D D / F s$ and PCBs in Catalonia, over Spain: Health risks. Food Chem. Toxicol. 50, 399-408.

RAPORT RSSE SZCZECIN 2017. Wyniki badan steżenia pestycydów $w$ Szczecinie $w$ roku 2014 , 2015, 2016, 2017. Rejonowa Stacja Sanitarno-Epidemiologiczna w Szczecinie.

Richardson S. D., Plewa M. J., WAgner E. D., SCHOENY R., DEMARINI D. M., 2007. Occurrence, genotoxicity, and carcinogenicity of regulated and emerging disinfection by products in drinking water: a review and roadmap for research. Mut. Res. Genet. Toxicol. Environ. Mutagen. 636, 178-242.

Rodriguez C., COOK A., DEvine B., VAN Buynder P., LugG R., Linge K., Weinstein P., 2008. Dioxins, Furans and PCBs in recycled water for indirect potable reuse. Int. J. Environ. Res. Publ. Health 5, 356-367.

ShaO Y., HaN S., OUYANG J., Yang G., LiU W., MA L., LUO M., XU D., 2016. Organochlorine pesticides and polychlorinated biphenyls in surface water around Beijing. Environ. Sci. Pollut. Res. 23, 24824-24833.

SimazaKi D., Kubota R., SuZuKi T., AKiBa M., NISHIMURA T., KUNIKANE S., 2015. Occurrence of selected pharmaceuticals at drinking water purification plants in Japan and implications for human health. Water Res. 76, 187-200.

Stec M., KuRZEJa E., KościoŁeK A., PAwŁowsKa-GóRAL K., 2012. Zagrożenia wynikajace z narażenia na dioksyny $i$ dioksynopodobne polichlorowane bifenyle. Probl. Hig. Epidemiol. 93, 639-646.

SuleJ A. M., Polkowska Z., NAMIESNIK J., 2011. Contamination of runoff water at Gdansk airport (Poland) by polycyclic aromatic hydrocarbons (PAHs) and polychlorinated biphenyls (PCBs). Sensors 11, 1901-1920.

TRAN N. H., HU J., ONG S. L., 2013. Simultaneous determination of PPCPS, EDCs, and artificial sweeteners in environmental water samples using a single-step SPE coupled with HPLC-MS/MS and isotope dilution. Talanta $113,82-92$.

WAN X., PAN X., Wang B., ZHAO S., Hu P., LI F., 2011. Distributions historical trends and source investigation of polychlorinated biphenyls in Dianchi Lake China. Chemosphere 85, 361-367.

WaN Y., JONES P. D., HOLEM R. R., KHIM J. S., Chang H., KaY D. P., ROARK S. A., NEWSTED J. L., PATterson W. P., Giesy J.'P., 2010. Bioaccumulation of polychlorinated dibenzo-p-dioxins, dibenzofurans, and dioxin-like polychlorinated biphenyls in fishes from the Tittabawassee and Saginaw Rivers, Michigan, USA. Sci. Total Environ. 408, 2394-2401.

Wang G. S., Deng Y. Ch., Lin T. F., 2007. Cancer risk assessment from trihalomethanes in drinking water. Sci. Total Environ. 387, 8695.

WEE S. Y., ARIS A. Z., 2017. Endocrine disrupting compounds in drinking water supply system and human health risk implication. Environ. Int. 106, 207-233. 
WeI L., YANG Y., LI Q. X., WANG J. 2015. Composition, distribution, and risk assessment of organochlorine pesticides in drinking water sources in South China. Water Qual. Expos. Health 7, 89-97.

WITCZAK A., ABDEL-GAWAD H., 2012. Comparison of organochlorine pesticides and polychlorinated biphenyls residues in vegetables, grain and soil from organic and conventional farming in Poland. J. Environ. Sci. Health B 47, 343354.

WitcZAK A., CyBulski J., Mituniewicz-MateK A., DMYTRÓW I., 2018. Zmiany zawartości PCB w mleku pochodzacym $z$ mlekomatów $w$ okresie trzyletnim - próba oceny stopnia narażenia konsumentów. Żywność Nauka Technol. Jakość 116, 151-162.

Xu Y., LUO F., Pal A., Gin K. Y. H., Reinhard M., 2011. Occurrence of emerging organic contaminants in a tropical urban catchment in Singapore. Chemosphere 83, 963-969.

Younes M., GALAL-GORCHEV H., 2000. Pesticides in drinking water- a case study. Food Chem. Toxicol. 38, 87-90.

KOSMOS Vol. 68, 4, 659-667, 2019

Jacek Cybulski, Agata WitczaK, Kamila Pokorska-NiewiadA, MoniKa ZdyB

Department of Toxicology, Faculty of Food Sciences and Fisheries, West Pomeranian University of Technology in Szczecin, 3 Papieża Pawła VI Str., 71-459 Szczecin,E-mail: agata.witczak@zut.edu.pl

\section{SELECTED ORGANIC XENOBIOTICS IN DRINKING WATER AND HEALTH RISK}

\section{Summary}

Water used in the food industry, as well as in the preparation of food or beverages, must meet the requirements of drinking water regarding its purity. The aim of this work was the literature analyzis covering the most common types of organic xenobiotics found in drinking water, as well as in other types of water that could be a source of drinking water. The problem of the presence of persistent organic pollutants in surface waters as well as in drinking water is still valid and occurs in many regions of the world. In drinking water, due to the sources of its acquisition, there may be a variety of contaminants, including those often difficult to remove during routine purification methods. These include, for example, dioxins, PCBs, hexachlorobenzene (HCB), organochlorine pesticides, polycyclic aromatic hydrocarbons (PAHs), THMs, pharmaceutical residues. The existing EU directives and national regulations defining permissible concentrations of pollutants in drinking water do not cover many of these compounds. Therefore, extending the list of necessary tests of drinking water would increase the health safety of the consumers.

Key words: drinking water, health safety, organic xenobiotic, pesticides 